

\section{DISCLAIMER}

Portions of this document may be illegible in electronic image products. Images are produced from the best available original document. 


\title{
THE APPLICABILITY OF SAMPLE COLLECTION AND ANALYSIS IN SUPPORT OF NUCLEAR ARMS CONTROL AGREEMENTS
}

\author{
Raymond R. McGuire \\ Arms Control and Treaty Verification Program \\ Lawrence Livermore National Laboratory
}

Introduction:

Agreements are being negotiated to halt the spread of nuclear arms both within the declared nuclear weapons states and to states not heretofore declaring their possession. With the verification regime of the recently negotiated Chemical Weapons Convention (CWC) as a model, negotiators are considering variations of on-site inspection as formulas to enhance the assurance of compliance with future agreements. These on-site inspections may be part of a treaty dictated verification regime or one of a set of voluntary "confidence building" measures. In either case, the collection of material samples for analysis could be an integral component of the inspection as it is in the CWC. The following is an assessment of the applicability of sampling and analysis for compliance monitoring nuclear arms control agreements currently envisioned.

There are two essentially orthogonal ways of approaching this question of applicability: the consideration of the analytical questions and the consideration of the specifics of the individual agreements. This study is meant to utilize both approaches in examining the possible impact of sampling and analysis on compliance assessment.

First attention must be given to technical questions relating to the efficacy of sampling and analysis.

\section{Effectiveness of Sampling and Analysis:}

\section{Can Relevant Samples Be Obtained?}

One of the most important aspects of sampling and analysis for gaining compliance information is the collection of samples that contain the necessary analytes in quantifiable concentrations. This ability to quantify is more important in cases where a detectable amount of an analyte is always expected. This aspect differentiates analysis for nuclear agreements from analysis for chemical weapons (CW) or biological weapons (BW) control agreements where the mere detection of certain materials raises a compliance concern. Questions of sample homogeneity are also heightened.

The kinds of samples that may be required are varied. They include the following.

a. Process samples - These may be solids (powdered metals or metal oxides, or even solid bits of metal), liquids (aqueous solutions, organic liquids, etc.), or vapor/gases or particulates trapped on adsorbents. They may also be samples collected on wipes of process equipment or nearby surfaces. 
b. Product samples - These samples are more likely to be solids from surface scrapings or wipes of surfaces. They may also include gaseous samples if materials like $\mathrm{UF}_{6}$ are considered to be products.

c. Stockpile samples - The types of materials included here are identical with those listed under product samples. However, since further "packaging" may well have taken place, the samples could be significantly less accessible.

d. Waste samples - All waste streams, when they are fresh, contain the same elemental and molecular species as the process streams even though the relative concentrations of components will vary dramatically. (Since reactions may continue in waste streams, the molecular identity of constituents may change with time). The types of samples to be collected are similar to process samples.

e. Environmental samples - Environmental samples arise from the ancillary spread of material during production, storage or use. The analytes of interest are usually dissolved in or adsorbed on other media. Such media include water, soil and other adsorptive surfaces such as vegetation and filters. Atmospheric samples also fall into this category. Analyte concentrations may be significant if the samples are collected from closed vessels such as a storage container or the cavity resulting from an underground explosion.

f. Reference Standard samples - Since quantification is of such importance when dealing with nuclear issues, the acquisition of reference standards for comparison of signal amplitude becomes critical. Standards may need to be artificially prepared for certain materials to mimic sample aging.

\section{Can Significant Analyses Be Performed?}

In order to obtain consequential results from an analysis, the measurement technology must be well characterized and reliable. (Most of the procedures that would be applied for this purpose are well characterized and reliable.) Moreover, many samples must be separated into sub components and/or concentrated prior to the measurement. (Many of these sample preparation procedures are not so well characterized or reliable.) Some of the considerations relating to sample analyses are as follows.

a. Sensitivity / Resolution of analytical measurements - Since many of the important analytes may be present in only trace amounts, very sensitive techniques will be needed to obtain a signal to noise ratio sufficient for quantification. In addition, the technique must be capable of distinguishing between analytes having similar or nearly identical properties; e.g., two ions of the same mass number. Thus very high resolution will be needed in certain instances.

b. Accuracy of measurements - Obtaining accurate measures of concentration is complicated by the ability of the analyst to separate a component into an analyzable form (sample preparation) and by the fact that instrument response may not be linear over the necessary range of concentration. It is necessary to characterize the error in accuracy of the entire procedure (sample preparation and measurement) over the expected range of concentrations.

c. Reproducibility of measurements - Analytical data must be reproducible from day to day and from sample to sample. This requires that the instrumentation be well maintained and precisely calibrated. In addition, any sample preparation procedure must be well characterized and rigidly followed. 
d. Isotopic ratios - The analytical requirements ( $\mathrm{a}, \mathrm{b}$, and $\mathrm{c}$ above) may not be quite so demanding at all times. In some cases it will be satisfactory to obtain the ratio of the analyte of interest to a second analyte in the sample. For example the ratio of ${ }^{235} \mathrm{U}$ to $238 \mathrm{U}$ may be adequate, rather than having to attempt to measure the absolute concentration of ${ }^{235} \mathrm{U}$. In this case, the ${ }^{238} \mathrm{U}$ becomes a sort of "internal standard" for the analysis. Similar use of ratios of analytes may be extended to organic analysis.

e. Absolute quantification - In some cases it will be necessary to precisely measure the amount of analyte. This may be accomplished by a number of techniques. However, all of the techniques require that any sample preparation procedure be well characterized and rigorously followed and that the analytical measurement be carefully maintained, calibrated and operated. Reference standards will be required for instrument calibration and / or use as a quantification standard depending on the methodology selected.

f. Trace analysis - It may be necessary to quantitatively measure materials that are present in very low concentrations. As stated above, this will place a premium on the sensitivity of the instrumental method and on the capability of the analyst. In most cases, the concentration required for quantification is significantly higher than that needed for detection. Analysis of radioactive materials can be performed with good accuracy at lower concentrations and with smaller samples, if no preparation is necessary, than can the analysis of non radioactive materials.

g. "Hot" samples - Materials that are intrinsically radioactive or in which radioactivity can be induced, can be analyzed at lower concentrations and with smaller samples than non radioactive materials. However, handling radioactive samples presents other problems; particularly related to waste disposal, decontamination of equipment and safety. The analysis of radioactive samples may involve the use of instrumentation that is not easily transportable to the inspection site. It will frequently be necessary, therefore, to transport samples to an off-site laboratory and entail all of the logistical problems associated with the shipment of radioactive materials to include compliance with whatever national or international rules are applicable. The analysis of radioactive and non radioactive materials will probably not be performed on the same instruments or in the same laboratory, even if the same analytical technique is used for both types of materials. Special measures will be needed to ensure that the measurements are comparable.

h. Non radioactive analytes - Key analytes may be either organic or inorganic, non radioactive materials. In many cases it will be necessary to perform extensive sample preparation to isolate and concentrate these analytes. Since no sample preparation method is $100 \%$ effective, the technique selected will have to be well characterized and reproducibly followed so that comparable results are obtained with each application.

\section{Can Meaningful Interpretations Of The Data Be Made?}

Given that samples have been properly collected and that the analyses have been performed with the best available technology, there remains the question of whether the results can be interpreted meaningfully. It will be uncommon that the analytical evidence will be so powerful that it will point unambiguously to compliance or non compliance. It 
is more likely that the data will be consistent with either compliance or non compliance and conflict with the alternative. Thus the data will be indicative rather than absolute.

A very important question while interpreting the data is one of kinetics. It may be possible to effectively "date" the event that gives rise to the detected analyte and it will frequently be critical to do so. Whether the data indicates an ongoing activity or one that was terminated at some time in the past is a very important distinction to be made in the arms control arena. The dating of events by determining the ratios of radioactive isotopes having different half-lives is highly practical since the starting ratios are reasonably well known for most activities.

Finally, since certain nuclear activities will legitimately continue and presumably be declared, it will be crucial to distinguish such activity from that which is proscribed by the particular agreement. In some instances this distinction may be difficult as the signatures of the different activities will be very similar. This is the primary reason for the rigorous controls set up for the sampling and analysis activities.

\section{What Will Sampling And Analyses Cost?}

The cost of sampling and analyses is by no means trivial, particularly with the rigorous quality control measures to be enforced. Most samples will run in the neighborhood of $\$ 1000$ per analyte to be measured. Some particularly difficult (trace quantities, etc.) could run as much as a factor of ten higher. These cost projections do not include new facilities or equipment or analytical methods R\&D.

\section{The Arms Control Agreements:}

A number of arms control agreements are either under active negotiation or are envisioned for the near future. Both bilateral and multi-national negotiations are or will be occurring. These agreements will attempt to control a wide variety of activities ranging from the production of nuclear weapons relevant materials to the destruction of current weapon stocks and the control the nuclear material thus made available.

Although the details of such agreements are not yet available, certain forecasts can be made with some assurance. These predictions are summarized in Table 1.

The Nuclear Non-Proliferation Treaty is not included in this discussion since the negotiations for its extension have recently been completed. However, it should be noted that the collection and analysis of environmental samples is currently being assessed by the International Atomic Energy Agency (IAEA) to enhance its safeguard activities with quite positive results.

\section{Consideration of Individual Agreements:}

As the treaty (agreement) limited items or activities vary widely, it will be necessary to examine each agreement individually and in some detail. Two examples of such discussions are given here for a Comprehensive Test Ban Treaty (CTBT) and for a Materials Cut-Off agreement. 
Table 1. Current and near future Nuclear Arms Control Negotiations

\begin{tabular}{|l|l|l|l|l|}
\hline Agreement & Facilities & Inspected Material & Possible Analytes, etc. & Notes \\
\hline $\begin{array}{l}\text { Comprehensive Test } \\
\text { Ban Treaty }\end{array}$ & $\begin{array}{l}\text { Nuclear test sites, could } \\
\text { include smaller hydro } \\
\text { test facilities. }\end{array}$ & Fission products & $\begin{array}{l}\text { Isotope presence and } \\
\text { ratios }\end{array}$ & $\begin{array}{l}\text { The nature of the event } \\
\text { and the yield need to be } \\
\text { determined. }\end{array}$ \\
\hline $\begin{array}{l}\text { Dismantlement and } \\
\text { storage facilities for } \\
\text { Weapon Components }\end{array}$ & $\begin{array}{l}\text { Pantex, Y-12, possibly } \\
\text { Rocky Flats, } \\
\text { Analogous Russian } \\
\text { facilities }\end{array}$ & $\begin{array}{l}\text { Pits, possibly } \\
\text { secondaries }\end{array}$ & $\begin{array}{l}\text { Pu, HEU, Be, B, T, LiD, } \\
\text { LiH, possibly some } \\
\text { non-nuclear material }\end{array}$ & $\begin{array}{l}\text { It is important to trace } \\
\text { the material to actual } \\
\text { nuclear assemblies either } \\
\text { by physical } \\
\text { characteristics or some } \\
\text { other method. }\end{array}$ \\
\hline $\begin{array}{l}\text { Cessation of Pu } \\
\text { production. (Bilateral } \\
\text { Protocol) }\end{array}$ & $\begin{array}{l}\text { Hanford, Savannah } \\
\text { River, possibly storage } \\
\text { facilities. Analogous } \\
\text { Russian facilities }\end{array}$ & Reprocessing plants \\
$\begin{array}{l}\text { HEU purchase } \\
\text { transparency measures } \\
\text { (Bilateral Protocol) }\end{array}$ & $\begin{array}{l}\text { Portsmouth GDP, and } \\
\text { Russian facilities }\end{array}$ & $\begin{array}{l}\text { Russian HEU } \\
\text { cladding material, } \\
\text { shorter lived isotopic } \\
\text { impurities }\end{array}$ & $\begin{array}{l}\text { Time frame of operation } \\
\text { will be most important. } \\
\text { Only recent operation is } \\
\text { proscribed. }\end{array}$ \\
\hline $\begin{array}{l}\text { Special Nuclear Material } \\
\text { Cut-off }\end{array}$ & $\begin{array}{l}\text { Portsmouth, Paducah, } \\
\text { Oak Ridge, Savannah } \\
\text { River, Hanford, and } \\
\text { ICPP, Others if } \\
\text { Challenge Inspections } \\
\text { are involved. Analogous } \\
\text { foreign facilities }\end{array}$ & SNM (PU, HEU and T) & $\begin{array}{l}\text { Shanium isotopics, } \\
\text { especially minor, } \\
\text { isotopes (233, 234 and } \\
\text { 236) }\end{array}$ & $\begin{array}{l}\text { The most important } \\
\text { question is if the } \\
\text { material came from a activation } \\
\text { dismantled weapon. }\end{array}$ \\
\hline $\begin{array}{l}\text { Perhaps Tritium } \\
\text { F-12, Hanford, Rocky }\end{array}$ & $\begin{array}{l}\text { Like the Bilateral Pu } \\
\text { Cut-off cited above, the } \\
\text { important question will } \\
\text { be when the SNM was } \\
\text { made. Isotopic ratios of } \\
\text { trace elements could be a } \\
\text { key. }\end{array}$ \\
\hline $\begin{array}{l}\text { Excess US material } \\
\text { offered for IAEA } \\
\text { Safeguards }\end{array}$ & US Pu and HEU & $\begin{array}{l}\text { IAEA already performs } \\
\text { characterization of } \\
\text { material. }\end{array}$ \\
\hline
\end{tabular}


Sampling And Analysis In Support Of A Comprehensive Test Ban Treaty-- CTBT:

The Comprehensive Test Ban Treaty (CTBT), currently under negotiation in Geneva, will attempt to eliminate nuclear testing and to put into effect a verification regime capable of detecting violations. (There is an ongoing debate as to whether some level of "hydro-nuclear" testing will be allowed. The credibility of an effective verification regime for a ban on tests yielding only a few pounds or tens of pounds of nuclear yield is dubious at best). The verification regime now being discussed begins with the detection of . an anomalous (seismic) event and could proceed with a visit by an international team of inspectors to the site of the source of the anomalous event. The inspectors would attempt to gather sufficient evidence, by various measurements and observations, to attribute the event to a nuclear test or to some other phenomenon; e.g., earthquake or mining.

Since the verification inspections will occur sporadically and only after a triggering event, they can be considered to be analogous to the "Challenge Inspection" regime under the Chemical Weapons Convention (CWC). It has, in fact, been suggested that a CTBT inspection could be instigated by an individual State Party to take place on the territory of another State Party. This is directly analogous to the CWC procedure.

One of the tools that a CTBT inspection team will bring with them is the capability to collect various samples for analysis either at the inspection site or at some off-site location. Here we examine the probable effectiveness of sampling and analysis in contributing to the verification process.

An excellent reference for the following discussion is CD/NTB/WP.xxx dated 13 December 1994, entitled "On-Site Inspection for the Comprehensive Test Ban Treaty: Phenomena, Technology, OSI Examples , Costs."

The types of samples that may be collected and the proposed analytes will depend on the nature of the suspect test (underground, underwater or atmospheric), the volatility of the analytes in question, and the elapsed time between the suspect event and the inspection of the site. These considerations are summarized in Table 2 and discussed below.

\section{Suspect Underground Events:}

The most commonly accepted inspection scenario would begin with the detection of an anomalous seismic event. An international inspection team would, after some as yet undetermined delay for fact finding and negotiation, arrive in the general vicinity of the suspect site. At this time the suspect site could be hundreds of square kilometers in area. As is the case for any sampling endeavor, the most important decision is where to collect the sample. Depending on the depth of burial and other factors, (assuming a nuclear test actually took place), the exact location of the event may or may not be easily determined. Unless an extensive and expensive statistically based sample collection protocol is to be enacted, it will be necessary to narrow the search area considerably. 
Table 2. Sampling And Analysis In Support Of A CTBT

\begin{tabular}{|c|c|c|c|c|c|c|}
\hline $\begin{array}{l}\text { Suspect Test } \\
\text { Venue }\end{array}$ & Sample Type & Collectability & Analyzability & Interpretability & \begin{tabular}{|l|} 
Relative \\
Cost
\end{tabular} & Comments \\
\hline Underground & $\begin{array}{l}\text { Gas, short lived } \\
\text { Radioactivity, } \\
{ }^{135} \mathrm{Xe},{ }^{133} \mathrm{Xe} \text {, } \\
\text { some }{ }^{131} \mathrm{Xe}\end{array}$ & $\begin{array}{l}\text { Short half-life, } \\
\text { (9hr \& 5dy), } \\
\text { need quick } \\
\text { response ( } 2 \text { wk } \\
-4 w k \text { ), } \\
\text { Possibly need } \\
\text { shallow well } \\
\end{array}$ & $\begin{array}{l}\mathrm{b}^{-} \text {and } \mathrm{g} \\
\text { emitters, } \\
\text { analyzed by } \\
\text { counting. }\end{array}$ & $\begin{array}{l}\text { Finding these } \\
\text { isotopes is good } \\
\text { evidence of a } \\
\text { nuclear } \\
\text { explosion. No } \\
\text { background } \\
\text { problem. }\end{array}$ & $\begin{array}{l}\text { Analysis cost } \\
\text { is low. } \\
\text { Collection } \\
\text { cost could be } \\
\text { moderate if } \\
\text { site survey } \\
\text { required. } \\
\end{array}$ & $\begin{array}{l}\text { Conditions need } \\
\text { to be just right to } \\
\text { find these } \\
\text { isotopes. Short } \\
t_{1 / 2} \text { shows recen } \\
\text { event. }\end{array}$ \\
\hline Underground & $\begin{array}{l}\text { Gas, Long lived } \\
{ }^{85} \mathrm{Kr},{ }^{37} \mathrm{Ar}\end{array}$ & $\begin{array}{l}\text { Longer half- } \\
\text { life allows for } \\
\text { diffusion. } \\
\text { Shallow well } \\
\text { may be needed }\end{array}$ & $\begin{array}{l}\text { Analyzed by } \\
\text { counting. }{ }^{37} \mathrm{Ar} \\
\text { requires } \\
\text { special } \\
\text { technique for } \\
\text { low energy } \\
\text { X-ray. }\end{array}$ & $\begin{array}{l}85 \mathrm{Kr} \\
\text { background } \\
\text { problem. } \\
\text { Finding these } \\
\text { isotopes is good } \\
\text { evidence of a } \\
\text { nuclear } \\
\text { explosion. }\end{array}$ & $\begin{array}{l}\text { Analysis cost } \\
\text { is low. } \\
\text { Collection } \\
\text { cost could be } \\
\text { moderate if } \\
\text { site survey } \\
\text { required. }\end{array}$ & $\begin{array}{l}\text { Longer } t_{1 / 2} \text { may } \\
\text { cause background } \\
\text { problem. Former } \\
\text { test sites may } \\
\text { give residual } \\
\text { signals. }\end{array}$ \\
\hline Underground & $\begin{array}{l}\text { Gas, Naturally } \\
\text { occurring, } \mathrm{CO}_{2} \text {, } \\
\mathrm{CH}_{4}, \mathrm{Rn}, \mathrm{H}_{2}\end{array}$ & $\begin{array}{l}\text { May be } \\
\text { collected from } \\
\text { shallow well. }\end{array}$ & $\begin{array}{l}\text { Gases } \\
\text { analyzed by } \\
\text { MS. }\end{array}$ & $\begin{array}{l}\text { Not definitive, } \\
\text { look for change } \\
\text { in flow rate. } \\
\text { Comparative } \\
\text { measure needed } \\
\text { before event. }\end{array}$ & $\begin{array}{l}\text { Low, may be } \\
\text { increased if } \\
\text { drilling } \\
\text { required. }\end{array}$ & $\begin{array}{l}\text { Normal flow } \\
\text { disturbed by } \\
\text { explosion. Not } \\
\text { definitive. Not } \\
\text { recommended. }\end{array}$ \\
\hline Underground & $\begin{array}{l}\text { Environmental / } \\
\text { vegetation }\end{array}$ & $\begin{array}{l}\text { Easily } \\
\text { collected, long } \\
\text { time after } \\
\text { event }\end{array}$ & $\begin{array}{l}\text { extensive } \\
\text { sample } \\
\text { preparation } \\
\text { needed }\end{array}$ & $\begin{array}{l}\text { Look for } \\
\text { increase in trace } \\
\text { radioactive } \\
\text { elements, fallout } \\
\text { background a } \\
\text { problem. }\end{array}$ & $\begin{array}{l}\text { Relatively } \\
\text { low cost, app. } \\
\$ 1000 \text { per } \\
\text { sample. }\end{array}$ & $\begin{array}{l}\text { Long fime needed } \\
\text { for plant } \\
\text { ingestion. Not } \\
\text { definitive. Not } \\
\text { recommended. }\end{array}$ \\
\hline
\end{tabular}


Table 2. Sampling And Analysis In Support Of A CTBT (Cont.)

\begin{tabular}{|c|c|c|c|c|c|c|}
\hline $\begin{array}{l}\text { Suspect Test } \\
\text { Venue }\end{array}$ & Sample Type & Collectability & Analyzability & Interpretability & $\begin{array}{l}\text { Relative } \\
\text { Cost }\end{array}$ & Comments \\
\hline Underground & $\begin{array}{l}\text { Cavity Debris, } \\
\text { non-volatile } \\
\text { fission products } \\
\text { possibly some } \\
\text { actinides, (if } \\
\text { allowed) }\end{array}$ & $\begin{array}{l}\text { Requires drill- } \\
\text { back into } \\
\text { cavity. }\end{array}$ & $\begin{array}{l}\text { Analyzed by } \\
\text { gamma ray } \\
\text { spectrometry / } \\
\text { ICPMS after } \\
\text { sample } \\
\text { preparation. }\end{array}$ & $\begin{array}{l}\text { Definite for } \\
\text { nuclear test. }\end{array}$ & $\begin{array}{l}\text { Very high } \\
\text { cost. }\end{array}$ & $\begin{array}{l}\text { Large drill rig } \\
\text { needed along with } \\
\text { extensive site } \\
\text { survey. } \\
\text { Decontamination } \\
\text { needed. }\end{array}$ \\
\hline Under water & $\begin{array}{l}\text { Gas, short lived } \\
\text { Radioactivity, } \\
{ }^{135} \mathrm{Xe},{ }^{133} \mathrm{Xe} \text {, } \\
\text { some }{ }^{131} \mathrm{Xe} \text {. }\end{array}$ & $\begin{array}{l}\text { High volume } \\
\text { air sampler, } \\
\text { need to find } \\
\text { plume, } \\
\text { Aircraft } \\
\text { needed. }\end{array}$ & $\begin{array}{l}\mathrm{b}^{-} \text {and } \mathrm{g} \\
\text { emitters, } \\
\text { analyzed by } \\
\text { counting. }\end{array}$ & $\begin{array}{l}\text { Gases vented, } \\
\text { atmospheric } \\
\text { models needed } \\
\text { to trace back to } \\
\text { event site, } \\
\text { definitive. }\end{array}$ & $\begin{array}{l}\text { Moderate } \\
\text { because of } \\
\text { need to detect } \\
\text { plume. }\end{array}$ & $\begin{array}{l}\text { Conditions need } \\
\text { to be just right to } \\
\text { find these } \\
\text { isotopes. Short } \\
t_{1 / 2} \text { shows recent } \\
\text { event. }\end{array}$ \\
\hline Under water & $\begin{array}{l}\text { Gas, Long lived } \\
{ }^{85} \mathrm{Kr} \text {, Possibly } \\
\text { some }{ }^{37} \mathrm{Ar}\end{array}$ & $\begin{array}{l}\text { High volume } \\
\text { air sampler/ } \\
\text { aircraft needed } \\
\text { to find plume, }\end{array}$ & $\begin{array}{l}\text { Analyze by } \\
\text { counting. }{ }^{85} \mathrm{Kr} \\
\text { for } \mathrm{g} \text { ray, }{ }^{37} \mathrm{Ar} \\
\text { for } \mathrm{X} \text {-ray }\end{array}$ & $\begin{array}{l}\text { Gases vented, } \\
\text { atmospheric } \\
\text { models needed, } \\
\text { good evidence }\end{array}$ & $\begin{array}{l}\text { Moderate } \\
\text { because of } \\
\text { need to detect } \\
\text { plume }\end{array}$ & $\begin{array}{l}\text { Significant } 85 \mathrm{Kr} \\
\text { background from } \\
\text { previous nuclear } \\
\text { activities. }\end{array}$ \\
\hline Under water & $\begin{array}{l}\text { Non volatile } \\
\text { fission products } \\
\text { and mutants. }\end{array}$ & $\begin{array}{l}\text { Need to find } \\
\text { plume. Grab } \\
\text { samples } \\
\text { usually } \\
\text { sufficient, } \\
\text { Boat / aircraft } \\
\text { needed. }\end{array}$ & $\begin{array}{l}\text { Possible need } \\
\text { for single } \\
\text { particle } \\
\text { analysis. }\end{array}$ & $\begin{array}{l}\text { Definitive for } \\
\text { nuclear test }\end{array}$ & $\begin{array}{l}\text { Moderate to } \\
\text { high because } \\
\text { of need to } \\
\text { detect plume } \\
\text { by boat or } \\
\text { aircraft, for } \\
\text { single particle } \\
\text { analysis \& } \\
\text { models for } \\
\text { trace back }\end{array}$ & $\begin{array}{l}\text { Attribution } \\
\text { difficult or } \\
\text { impossible. Other } \\
\text { evidence needed } \\
\text { to define event } \\
\text { site. }\end{array}$ \\
\hline
\end{tabular}


Table 2. Sampling And Analysis In Support Of A CTBT (Cont.)

\begin{tabular}{|l|l|l|l|l|l|l|}
\hline $\begin{array}{l}\text { Suspect Test } \\
\text { Venue }\end{array}$ & Sample Type & Collectability & Analyzability & Interpretability & Relative Cost & Comments \\
\hline $\begin{array}{l}\text { Atmospheric / } \\
\text { low altitude }\end{array}$ & $\begin{array}{l}\text { Radioactive } \\
\text { gases and other } \\
\text { fission } \\
\text { products, } \\
\text { perhaps } \\
\text { activation } \\
\text { products. }\end{array}$ & $\begin{array}{l}\text { High volume } \\
\text { air sampler } \\
\text { needed, need } \\
\text { aircraft or } \\
\text { ground station } \\
\text { network }\end{array}$ & $\begin{array}{l}\text { Single particle } \\
\text { analysis } \\
\text { needed for non } \\
\text { volatile fission } \\
\text { products, etc. }\end{array}$ & $\begin{array}{l}\text { Definitive for } \\
\text { nuclear test. } \\
\text { Must be } \\
\text { significant over } \\
\text { background. }\end{array}$ & $\begin{array}{l}\text { Moderate to } \\
\text { high because } \\
\text { of need for } \\
\text { aircraft and } \\
\text { single particle } \\
\text { analysis }\end{array}$ & $\begin{array}{l}\text { Attribution } \\
\text { difficult or } \\
\text { impossible if over } \\
\text { ocean. }\end{array}$ \\
\hline $\begin{array}{l}\text { Atmospheric / } \\
\text { low altitude }\end{array}$ & $\begin{array}{l}\text { Environmental } \\
\text { samples for } \\
\text { fission product } \\
\text { fallout. }\end{array}$ & $\begin{array}{l}\text { Easily } \\
\text { collected once } \\
\text { surface } \\
\text { radioactivity } \\
\text { detected. }\end{array}$ & $\begin{array}{l}\text { Gamma ray } \\
\text { spectrometry, } \\
\text { ICPMS or } \\
\text { single particle } \\
\text { analysis. }\end{array}$ & $\begin{array}{l}\text { Quantization } \\
\text { needed to } \\
\text { separate from } \\
\text { background }\end{array}$ & $\begin{array}{l}\text { Low to } \\
\text { moderate }\end{array}$ & $\begin{array}{l}\text { Only applicable } \\
\text { if over ground. }\end{array}$ \\
\hline
\end{tabular}


Gas Sampling - Assuming that sampling locations have been determined, the first samples collected will be gas samples. In particular, inspectors will seek to determine the presence of isotopes of the noble gases Xenon ( ${ }^{131} \mathrm{Xe},{ }^{133} \mathrm{Xe}$ and $\left.{ }^{135} \mathrm{Xe}\right), \mathrm{Krypton}\left({ }^{85} \mathrm{Kr}\right)$ and Argon ( $\left.{ }^{37} \mathrm{Ar}\right)$ as these are essentially definitive for nuclear fission although not necessarily for nuclear explosives testing. (If a sample can be collected soon enough after the event, the ratios of these isotopes are highly definitive for a nuclear explosion.) Other cvidence drawn from the inspection site may be needed for more definitive conclusions. The xenon and krypton isotopes are fission products. The argon arises from the intense neutron bombardment of calcium atoms both in the device and in the soil. Depending on the concentration of the gases, the xenon and krypton isotopes can be measured by gamma ray spectrometry and beta counting. The argon must be determined in a special device (internal gas proportional counter) that can detect the low energy $x$-ray emitted during its decay.

The detection of the xenon isotopes is particularly important because their short half-lives ( $131 \mathrm{mXe}=11.92$ days, ${ }^{133} \mathrm{Xe}=5.25$ days and ${ }^{135} \mathrm{Xe}=9.10$ hours) allow for the dating of the event to a fairly close approximation. However, if access to the site and sample collection does not occur within a month of the suspect event, the probability of finding these isotopes is very low.

The longer half-lives of the krypton and argon $\left({ }^{85} \mathrm{Kr}=10.72\right.$ years and ${ }^{37} \mathrm{Ar}=34.8$ days) increases the probability of their detection even a year or so after the event. In fact, the long $t_{1 / 2}$ complicates the background measurement. This is especially true for the krypton where a significant background level has resulted from the reprocessing of nuclear fuel. In either case, the detected levels must be significantly above normal background if the measurements are to used for inspection purposes.

All things considered, the ${ }^{37} \mathrm{Ar}$ becomes the analyte of primary interest; even though this isotope is difficult to determine. The necessary analytical methodology has been developed and applied with quite good results.

The flow and distribution of naturally occurring gases such as carbon dioxide, methane, hydrogen and radon can be significantly changed as a result of an underground nuclear explosion. Similar changes could also result from other phenomena such as an earthquake. In any case, the conditions prior to the event would have to be known before conclusions could be drawn. (The presence of radon is frequently used as an indicator that the collected sample is representative of underground gases). Such samples would not be recommended.

Before going on to other sample types, some discussion should be made concerning the collection of gas samples. Since the xenon, krypton and argon are formed in the immediate vicinity of the actual explosion, they must migrate to the surface. Beyond the fracture zone, this migration is by diffusion and advection through cracks and can take weeks or months depending on the geology. The sampling can be accelerated by the drilling of shallow wells or implacing penetrometers. If wells are needed, access to a drilling rig is required. Extensive drilling can be a costly and time consuming endeavor. 
Environmental Samples - Environmental samples such as soil and vegetation will only show evidence of an underground nuclear explosion after a period of time long enough for the fission products, etc. to migrate through ground water and, if plants, be ingested. This can take years. Such samples would not be recommended.

Samples from the Explosion Cavity - If samples can be obtained directly from the explosion cavity, the analysis for non-volatile fission products and some longer lived actinides will be definitive. Some useful measurements can be performed with portable gamma spectrometers to determine the ratios of some of the fission products. This will allow the dating of the event with reasonably good accuracy. Further analysis by mass spectrometric techniques (ICPMS or TIMS) can divulge sensitive information about device design and may not be allowed.

However, the collection of such samples is very expensive as it requires drilling back into the explosion cavity. In the absence of evidence at the surface to pin-point the drilling site, locating the cavity can also be expensive and time consuming. Even after the site is localized, a significant and expensive drilling capability will be needed to enter the cavity without venting radioactivity to the environment.

Based on the above discussion, it must be concluded that the analysis of samples collected at a suspect site can be definitive for an underground muclear explosion. To some level of detectability, analyses by radiation counting can be performed at the inspection site. Lower levels of detection can be achieved in an off-site laboratory. Analyses of non volatile materials by mass spectrometry and single particle analyses must be done off site.

However, the cost of collecting such samples can be prohibitive, particularly if the event site cannot be localized by other means. A protocol for making decisions on when and how to proceed with sample collection should be agreed to before the onset of inspections.

\section{Suspect Under Water Events:}

A second possible site for clandestine nuclear testing is the open ocean (or possibly a large sea or lake). In any case, the hot gases, including the Xenon, Krypton and Argon isotopes cited above, will be vented to the atmosphere carrying with them other radioactive materials. (One possible exception to this venting is an explosion very deep under water). The remaining explosion products will rise more slowly, cool and be, in time, dispersed by the currents and diffusion. Sample collection is therefore resolved into two parts; air sampling of the ejecta and water sampling of the retained products.

Although one would expect to see much smaller amounts of ${ }^{37} \mathrm{Ar}$ from under water explosions because of the lack of calcium bearing soil, the other expected products will be similar to those discussed for underground explosions. The analyses, with one exception, and interpretation of results is likewise the same. Although good results can be obtained by analyzing bulk samples, the analysis of single debris particles for explosion related isotopes will likely play a major role relative to these types of inspections. 
Air Sampling - The collection of samples of ejecta will generally require aircraft deployed with high volume air samplers or a network of static samplers. Since the concentration of analytes will relatively quickly drop below levels clearly distinguishable above background, due to dispersion and rain-out / fall-out, collections must be made within a week or two of the suspect event. The collection and analysis of Xenon isotopic ratios can be accomplished later as these are permanent gases. Even then it will probably be necessary to use good atmospheric computer models to narrow the search volume to practical limits.

Water Sampling - The products retained in the water will disperse more slowly that those in the atmosphere. One could expect to be able to collect significant samples for up to a couple of months after the suspect event. High volume water samplers will probably be used, although grab samples may be adequate if the concentration is high enough. Samplers may be deployed from either boats or aircraft (helicopter). Similar to the case of atmospheric sampling, hydrologic models may be needed to define probable search areas.

\section{Suspect Atmospheric Events:}

The discussion of sampling and analysis under this type of event is much the same as the discussion of air sampling after an under water event. This includes the expected lower concentration of ${ }^{37} \mathrm{Ar}$, the utility of analyzing single debris particles and the time limits imposed by atmospheric dispersion and rain-out / fall-out.

Another aspect is added if the event takes place over ground at low altitude. In this case, a large amount of surface material can be entrained and made radioactive. Traces of this material can be detected because of its radioactivity as it falls back to the earth surface. Atmospheric models would again be used to predict the fall-out pattern for sample collection. Care must be exercised in interpreting these data so as to distinguish them from radioactivity arising from fall-out from previous atmospheric nuclear tests and from the Chernobyl accident.

The analysis of both atmospheric and water samples can be definitive for a muclear explosion. However, care must be taken to distinguish gas sample results from background. These results could also arise from a fission event other than a muclear explosion. The detection of non volatile fission products is more definitive but will require single particle analysis unless a sufficiently large agglomeration of particles can be collected.

Hydronuclear Testing:

There has been discussion at the $\mathrm{CD}$ as to whether hydronuclear testing will be allowed under a CTB. In any case the detection of such a low yield event through seismic activity is extremely unlikely. However, once a hydronuclear is either declared or somehow suspected, the analysis of samples collected at the site will be useful in determining if a nuclear event actually took place at a suspected site (equivalent to a "challenge Inspection" under the CWC), or what the actual yield was in the case of a declared test. 
Sampling and Analysis in Support of Nuclear Materials Control/Cut Off:

There have been a large number of field sampling experiments around the world that have examined the question of the effectiveness of collecting environmental samples for analysis to detect various activities related to the production of nuclear materials. These range from environmental monitoring of the reactors at Savannah River and Hanford to the Iraq War to the $93+2$ study currently underway at the IAEA to examine methods to enhance Safeguard Inspections..All have pretty much concluded that if the samples are properly collected and protected from subsequent cross contamination, activities associated with a subject site can be detected whether declared or not. The kinds of activities that may be monitored as a result of a nuclear materials control / cut off agreement are given in Table 3 along with some of the analytes that would be useful for such monitoring.

The fact the analytes of interest can be detected in very low concentrations, (as low as 1 in $10^{14}$ to $10^{16}$ in some instances), has been well established. The problems that arise deal with distinguishing legitimate activity from that which is proscribed and in dating activities to show that they have occurred after they were claimed to have been terminated.

\section{Plutonium producing reactors:}

All reactors that use ${ }^{238} \mathrm{U}$ in any amount will produce plutonium. The question therefore becomes "How do you detect plutonium that is intended for illicit use?". Some clues as to the intended use for the plutonium can be obtained by detailed elemental analysis to determine ratios of $\mathrm{Pu}$ isotopes and the relative amount of certain fission products such as ${ }^{148} \mathrm{Nd}$. This is because the greater the percentage of the 240 isotope and the 241 isotope in the plutonium relative to the 239 isotope, the less suitable it is for use in nuclear weapons. (These isotopes have high rates of gamma and neutron emission which both decrease the predictability of the warhead performance and make the materials more hazardous to work with.) This is not to say, however, that a cruder warhead could not be produced from plutonium with a relatively high level of isotopic impurities.

The ${ }^{240} \mathrm{Pu}$ and ${ }^{241} \mathrm{Pu}$ are formed by neutron capture by the ${ }^{239} \mathrm{Pu}$. If the $\mathrm{Pu}$ is to be used for weapons production, there is a trade-off to be made in the time of exposure of the $238 \mathrm{U}$ to the neutron flux. (This is generally expressed as burn-up time in megawatt days per ton of fuel, $\mathrm{MWd} / \mathrm{t}$ ). More ${ }^{239} \mathrm{Pu}$ is formed with longer burn-up time but the impurity level increases even more rapidly.

If samples of the reactor fuel can be obtained, after removal from the reactor and cooling to allow the shorter half-life and more highly radioactive materials to decay, the burn-up time can be approximated, and thus some indication of the intended use of the plutonium can be obtained. The $240 \mathrm{Pu} / 239 \mathrm{Pu}$ ratio can be measured directly with a secondary check made by measuring the quantity of ${ }^{148} \mathrm{Nd}$, a non radioactive fission product in the spent fuel.

It will be important, in cases where there may be some ambiguous results, to attempt to date the sample deposition. The date of the activity can be approximated by determining the ratios of certain of the radioactive fission products; e.g., ${ }^{134} \mathrm{Cs} /{ }^{137} \mathrm{Cs}$, by gamma ray spectrometry. 
Table 3. Sampling and Analysis at Facilities Under Nuclear Material Production Controls

\begin{tabular}{|c|c|c|c|c|c|c|}
\hline $\begin{array}{l}\text { Suspect Test } \\
\text { Venue }\end{array}$ & Sample Type & Collectability & Analyzability & Interpretability & Relative Cost & Comments \\
\hline $\begin{array}{l}\text { Plutonium } \\
\text { producing } \\
\text { reactor }\end{array}$ & \begin{tabular}{|l|} 
1.Material \\
samples \\
2.Environmental \\
samples \\
3. Gas samples
\end{tabular} & \begin{tabular}{|l|} 
1. Cooperation of \\
host required. Wipe \\
samples more likely \\
than others. \\
Probably not useful. \\
2. Soil, water, \\
sediment, and \\
biota/vegetation \\
samples easily \\
obtained. \\
3. Gas sampling \\
probably not useful.
\end{tabular} & \begin{tabular}{|l} 
Ratio of \\
$240 \mathrm{Pu}$ to \\
239Pu \\
requires MS \\
(TIMS) \\
148 Nd. \\
(ICPMS)
\end{tabular} & $\begin{array}{l}\text { Isotopic ratios and } \\
148 \mathrm{Nd} \text { content can } \\
\text { indicate burn time }\end{array}$ & $\begin{array}{l}\text { Average cost } \\
\text { of analysis is } \\
\$ 1000 \text { per } \\
\text { sample per } \\
\text { procedure }\end{array}$ & $\begin{array}{l}\text { Low } 240 \mathrm{Pu} \text { and/or } \\
\text { low } 148 \mathrm{Nd} \\
\text { indicates possible } \\
\text { intent to use as } \\
\text { weapons material. } \\
\text { Ratios of fission } \\
\text { product and } \\
\text { activation product } \\
\text { isotopes may be } \\
\text { useful to date } \\
\text { activity. Not } \\
\text { generally cost } \\
\text { effective to sample. }\end{array}$ \\
\hline $\begin{array}{l}{ }^{233} \mathrm{U} \text { producing } \\
\text { reactor }\end{array}$ & \begin{tabular}{|l|} 
1.Material \\
samples \\
2.Environmental \\
samples \\
3. Gas samples
\end{tabular} & \begin{tabular}{|l|} 
1. Cooperation of \\
host required. Wipe \\
samples more likely \\
than others. \\
Probably not useful. \\
2. Soil, water, \\
sediment, and \\
biota/vegetation \\
samples easily \\
obtained. \\
3. Gas sampling \\
probably not useful.
\end{tabular} & $\begin{array}{l}\text { Detection of } \\
233 \mathrm{U} \text { and } \\
{ }^{232} \mathrm{Th} \text { by MS } \\
\text { or gamma } \\
\text { spectrometry. }\end{array}$ & $\begin{array}{l}\text { Detection of } \\
\text { analytes is } \\
\text { definitive }\end{array}$ & $\begin{array}{l}\text { Average cost } \\
\text { of analysis is } \\
\$ 1000 \text { per } \\
\text { sample per } \\
\text { procedure }\end{array}$ & $\begin{array}{l}\text { Production of } 233 \mathrm{U} \\
\text { indicates possible } \\
\text { intent to use as } \\
\text { weapons material. } \\
\text { Ratios of fission } \\
\text { product and } \\
\text { activation product } \\
\text { isotopes may be } \\
\text { useful to date } \\
\text { activity. Not } \\
\text { generally cost } \\
\text { effective to sample. }\end{array}$ \\
\hline
\end{tabular}


Table 3. Sampling and Analysis at Facilities Under Nuclear Material Production Controls (cont.)

\begin{tabular}{|c|c|c|c|c|c|c|}
\hline $\begin{array}{l}\text { Suspect Test } \\
\text { Venue }\end{array}$ & Sample Type & Collectability & Analyzability & Interpretability & Relative Cost & Comments \\
\hline $\begin{array}{l}\text { Tritium } \\
\text { producing } \\
\text { reactor }\end{array}$ & $\begin{array}{l}\text { 1.Material } \\
\text { samples } \\
\text { 2.Environmental } \\
\text { samples } \\
\text { 3. Gas samples }\end{array}$ & $\begin{array}{l}\text { 1. Cooperation of } \\
\text { host required. Wipe } \\
\text { samples more likely } \\
\text { than others. } \\
\text { Probably not useful. } \\
\text { 2. Soil, water, } \\
\text { sediment, and } \\
\text { biota/vegetation } \\
\text { samples easily } \\
\text { obtained. } \\
\text { 3. Gas sampling } \\
\text { probably not useful. }\end{array}$ & $\begin{array}{l}\text { Use atomic } \\
\text { absorption } \\
\text { spectrometry } \\
\text { for lithium, } \\
\text { MS for T and } \\
\mathrm{Li} \text { isotopics. } \\
\text { Beta spec. for } \\
\mathrm{T}\end{array}$ & $\begin{array}{l}\text { Detection of } \\
\text { analytes is } \\
\text { definitive }\end{array}$ & $\begin{array}{l}\text { Average cost } \\
\text { of analysis is } \\
\$ 1000 \text { per } \\
\text { sample per } \\
\text { procedure }\end{array}$ & $\begin{array}{l}\text { Production of large } \\
\text { quantities of tritium } \\
\text { indicates possible } \\
\text { intent to use as } \\
\text { weapons material. } \\
\text { Not generally cost } \\
\text { effective to sample. }\end{array}$ \\
\hline $\begin{array}{l}{ }^{235} \mathrm{U} \\
\text { enrichment } \\
\text { facility }\end{array}$ & $\begin{array}{l}\text { 1.Material } \\
\text { samples } \\
\text { 2.Environmental } \\
\text { samples } \\
\text { 3. Gas samples }\end{array}$ & $\begin{array}{l}\text { 1. Cooperation of } \\
\text { host required. Wipe } \\
\text { samples more likely } \\
\text { than others. } \\
\text { 2. Soil, water, } \\
\text { sediment, and } \\
\text { biota/vegetation } \\
\text { samples easily } \\
\text { obtained. } \\
\text { 3. Gas sampling } \\
\text { probably not useful. }\end{array}$ & $\begin{array}{l}\text { MS for } \\
\text { Uranium } \\
\text { isotopics. } \\
\text { ESCA } \\
\text { possible for } \\
\mathrm{UO}_{2} \mathrm{~F}_{2} . \\
\text { Single particle } \\
\text { analysis may } \\
\text { be needed }\end{array}$ & $\begin{array}{l}\text { High }{ }^{235} U \text { to } \\
238 \mathrm{U} \text { is definitive } \\
\text { for enrichment } \\
{ }^{236} \mathrm{U} \text { shows use of } \\
\text { reprocessed } U \text {. }\end{array}$ & $\begin{array}{l}\text { Average cost } \\
\text { of analysis is } \\
\$ 1000 \text { per } \\
\text { sample per } \\
\text { procedure. } \\
\text { Single partical } \\
\text { analysis is } \\
\$ 10000 \text { each }\end{array}$ & $\begin{array}{l}\text { Findings must be } \\
\text { compared with } \\
\text { declaration and } \\
\text { historical activities. } \\
\text { A primary focus } \\
\text { for sampling for } \\
\text { HEU. }\end{array}$ \\
\hline
\end{tabular}


Table 3. Sampling and Analysis at Facilities Under Nuclear Material Production Controls (cont.)

\begin{tabular}{|c|c|c|c|c|c|c|}
\hline $\begin{array}{l}\text { Suspect Test } \\
\text { Venue }\end{array}$ & Sample Type & Collectability & Analyzability & Interpretability & $\begin{array}{l}\text { Relative } \\
\text { Cost }\end{array}$ & Comments \\
\hline $\begin{array}{l}\text { Reprocessing } \\
\text { facilities for } \mathbf{P u} \\
\text { and }{ }^{233} \mathbf{U}\end{array}$ & $\begin{array}{l}\text { 1.Material } \\
\text { samples } \\
\text { 2.Environmental } \\
\text { samples } \\
\text { 3. Gas samples }\end{array}$ & $\begin{array}{l}\text { 1. Cooperation of } \\
\text { host required. Wipe } \\
\text { samples more likely } \\
\text { than others. } \\
\text { 2. Soil, water, } \\
\text { sediment, and } \\
\text { biota/vegetation } \\
\text { samples easily } \\
\text { obtained. } \\
\text { 3. Stack effluents } \\
\text { can be collected. }\end{array}$ & $\begin{array}{l}\text { MS for U and } \\
\text { Pu isotopics. } \\
\text { Gamma spec. } \\
\text { for Xe and } \mathrm{Kr} \\
\text { isotopics. } \\
\text { Organics by } \\
\text { MS. Some } \\
\text { samples could } \\
\text { have high } \\
\text { radioactivity. } \\
\text { Single particle } \\
\text { analysis may } \\
\text { be needed } \\
\end{array}$ & $\begin{array}{l}\text { Organic analysis } \\
\text { only indicative. } \\
\text { Isotopic plus } \\
\text { organic analyses are } \\
\text { definitive. } \\
\text { Identification of } \\
\text { fission fragments, } \\
\text { activation and } \\
\text { decay products can } \\
\text { give production } \\
\text { details. }\end{array}$ & $\begin{array}{l}\text { Average cost } \\
\text { of analysis is } \\
\$ 1000 \text { per } \\
\text { sample per } \\
\text { procedure } \\
\text { Single partical } \\
\text { analysis is } \\
\$ 10000 \text { each }\end{array}$ & $\begin{array}{l}\text { Ratios of fission } \\
\text { product and } \\
\text { activation product } \\
\text { isotopes may be } \\
\text { useful to date } \\
\text { activity. Ratios of } \\
\text { Xe and } \mathrm{Kr} \text { isotopes } \\
\text { may be useful in } \\
\text { determining fuel } \\
\text { burnup. } \\
\text { A primary focus } \\
\text { for sampling. }\end{array}$ \\
\hline $\begin{array}{l}\text { Fuel and Target } \\
\text { Fabrication } \\
\text { Facility }\end{array}$ & $\begin{array}{l}\text { 1.Material } \\
\text { samples } \\
\text { 2.Environmental } \\
\text { samples } \\
\text { 3. Gas samples }\end{array}$ & $\begin{array}{l}\text { 1. Cooperation of } \\
\text { host required. Wipe } \\
\text { samples more likely } \\
\text { than others. } \\
\text { 2. Soil, water, } \\
\text { sediment, and } \\
\text { biota/vegetation } \\
\text { samples easily } \\
\text { obtained. } \\
\text { 3. Gas sampling not } \\
\text { useful. }\end{array}$ & $\begin{array}{l}\text { Atomic } \\
\text { Absorption } \\
\text { spec. for } \mathrm{Li} \text {. } \\
\mathrm{MS} \text { or } \mathrm{g} \text { spec } \\
\text { for } \mathrm{Th} \text {. and } \mathrm{U} \\
\text { and } \mathrm{Pu} \\
\text { isotopics. }\end{array}$ & $\begin{array}{l}\text { Determine fuel } \\
\text { composition and if } \\
\text { target material is to } \\
\text { be irradiated. }\end{array}$ & $\begin{array}{l}\text { Average cost } \\
\text { of analysis is } \\
\$ 1000 \text { per } \\
\text { sample per } \\
\text { procedure }\end{array}$ & $\begin{array}{l}\text { Make-up of fuel } \\
\text { rods and target } \\
\text { material indicates } \\
\text { intent. } \\
\text { An alternative } \\
\text { focus for sampling. }\end{array}$ \\
\hline
\end{tabular}


Samples may be acquired more easily at a reprocessing facility but may not then be traceable to a specific reactor.

\section{2. ${ }^{233} \mathrm{U}$ producing reactors:}

Another fissionable isotope that is suitable for nuclear weapons is ${ }^{233} \mathrm{U}$ even though it has not been a material of choice of declared nuclear weapon states. ${ }^{233} \mathrm{U}$ can also be used as a fuel in commercial power reactors; although, again, it has not been utilized to any extent, if at all. ${ }^{233} \mathrm{U}$ is formed by neutron irradiation of naturally occurring ${ }^{232} \mathrm{Th}$. Thus the detection of the use of thorium relative to a nuclear reactor is highly suggestive of an attempt to produce ${ }^{23} \mathrm{U}$.

\section{Tritium producing reactors:}

Tritium does have some commercial use and, if there is ever a fusion energy economy, will have a greatly expanded use. However, currently, the primary use of tritium is in thermonuclear weapons. Therefore, the discovery of a reactor being used for producing large quantities of tritium should indicate something other than commercial application.

Tritium is generally produced by irradiating lithium (either ${ }^{6} \mathrm{Li}$ or ${ }^{7} \mathrm{Li}$ ) with thermal neutrons. Thus the detection of lithium or lithium salts, (lithium metal being very reactive), is a very good indication of tritium production. In addition, the lithium rods to be irradiated are frequently clad with aluminum. This could be another indicator.

\section{4. ${ }^{235} \mathrm{U}$ enrichment facility:}

There are legitimate commercial uses for uranium containing ${ }^{235} \mathrm{U}$ content ranging from $0.71 \%$ (naturally occurring) to $>90 \%$ (highly enriched). (Greater than $20 \% 235 \mathrm{U}$ is generally classed as highly enriched (HEU), ${ }^{235} \mathrm{U}$ contents between natural and $20 \%$ are "low enrirched" uranium (LEU), and uranium with $235 \mathrm{U}$ content less than naturally occurring is termed "depleted uranium" (DU). US weapons grade uranium is $93 \% 235 \mathrm{U}$ ). Light water moderated power reactors (BLWRs and PLWRs) use low enriched uranium. Heavy water moderated power reactors, such as CANDU reactors, and graphite moderated reactors can use natural uranium as a fuel. HEU, in addition to its use in nuclear weapons, is used in many research reactors and naval power reactors. It is used in some gas cooled, graphite moderated power reactors.

The detection, therefore, of HEU does not necessarily indicate illicit activity unless the site is declared to produce only LEU. Because of the enrichment processes, the distribution of uranium isotopes will be essentially uniform. (It is not possible to have samples with enrichments of $90 \%$ and $5 \%$ in the same process sample.) Thus the detection of $235 \mathrm{U}$ concentration statistically greater than the declared enrichment level in a single sample is definitive that higher enrichments were being produced.

Besides the ${ }^{235} \mathrm{U} / 238 \mathrm{U}$ ratio, the detection of other analytes can yield significant information. For example, the detection of ${ }^{236} \mathrm{U}$ indicates that the feed uranium has been exposed to a reactor-like neutron flux and thus has probably been through reprocessing. If it is possible to obtain a sample of the feed, it may be feasible to determine the sample history including previous use, if any. (The chemical nature of the feed stock will vary to 
some extent depending on the enrichment process. Although the predominant gaseous feed is $\mathrm{UF}_{6}, \mathrm{UCl}_{4}$ has been used in electromagnetic separation processes (Calutrons) and other species may be used in chemical separation schemes.) It is less likely that uranium in environmental samples will be traceable as hydrolysis to the oxide occurs easily. In some cases, the intermediate oxyhalides, $\mathrm{UO}_{2} \mathrm{~F}_{2}$ and $\mathrm{UOCl}_{2}$ may be detected.

In any case, it is important that the analytical results be compared with the declared purjose and history of the facility.

\section{Reprocessing facilities:}

Once a fuel or target element has been exposed to the neutron flux in a reactor, it may be useful to recover either one or more of the materials resulting from the exposure or residual fuel for reuse. The procedure for this material recovery is called reprocessing. (If, as in US power reactors under current use policy, the fuel elements are only to be used once, reprocessing is not done.) Reprocessing is always necessary to obtain stocks of Pu, $\mathrm{T}$ and ${ }^{233} \mathrm{U}$. It is also frequently used to recycle HEU.

The existence of a process facility is relatively easy to deduce by the combination of organic process chemicals and the presence of radioactive materials such as plutonium. (The organic chemical by themselves, while indicative, are not definitive.) Moreover, because of the release of fission fragments, decay products and activation products during reprocessing, analyzing samples from product and waste streams can provide the complete history of the material being processed. Some of these products will be released as gases; e.g., $\mathrm{Xe}, \mathrm{Kr}$ and I isotopes, while others will be in the liquid waste streams. (It should be noted that some of the liquid or solid waste streams will be highly radioactive.) Even partial access can give important information such as the nature of any target materials and burn-up time that could indicate the intended use for the recovered components.

In view of the above discussion, it can be seen that a reprocessing facility is a prime candidate for sample collection in that all materials useful for weapons application, with the exception of HEU, must go through such a plant.

\section{Fuel fabrication facility:}

While it is not generally thought of as a sampling site, the fuel fabrication facility is a place where the intended use for the fuel can be inferred, to some extent, before the fact. The composition of fuel and target elements provide a clear measure of intent. For example: target elements of ${ }^{238} \mathrm{U}$ would show an intent to produce $\mathrm{Pu}$ in greater quantity than would arise from the fuel rod itself; targets of ${ }^{232} \mathrm{Th}$ show the certain intention to produce ${ }^{233} \mathrm{U}$; and $\mathrm{Li}$ targets definitely show Tritium as the intended product.

\section{Summary discussion of production facilities:}

As can be gathered from the above discussion, all facilities that would be affected by nuclear materials production controls do not provide equal opportunities for effective sample collection. However, collecting samples at two types of facilities will essentially cover the use of nuclear materials for weapons applications. These facilities: viz; uranium enrichment and reprocessing facilities, should be the primary focus of sample collection and analysis for verification of compliance with cut-off of nuclear material production. 
Sampling at the fuel and target fabrication can, to some extent, give similar information to that at a reprocessing facility.

Collecting samples at reactors should be avoided as being cost ineffective.

8. The IAEA experience:

Recently, the International Atomic Energy Agency (IAEA) has been looking at the collection and analysis of environmental samples, including wipe samples, as a method of enhancing Safeguards Inspections. Most of the analyses, which include radiation counting, thermal ionization mass spectrometry (TIMS), inductively coupled plasma mass spectrometry (ICPMS), and accelerator mass spectrometry (AMS), have been performed by US DOE laboratories. The results of these studies have clearly shown that it is possible to detect nuclear material production facilities without actually gaining access to the facility interiors. However, the studies have not attempted to determine the types of detailed process information discussed above.

\section{Summary and Conclusions:}

We have tried to show that sample collection and analysis can play a valuable role in the verification of nuclear arms control agreements. However, each case must be considered on its own merits.

While, for example, the analysis of samples collected from a nuclear test cavity will be definitive, the collection of such samples is, at best, very expensive and, at worst, uncollectable because the cavity cannot be exactly located. Samples at nuclear reactors are not likely to be productive unless actual fuel or target elements can be sampled after irradiation; yet, samples collected at reprocessing facilities can give important information of production details.

It is always profitable to ask the following questions.

1. What are the possible results of the analysis of the sample I am about to collect and which of them are most probable? and,

2. Given such and such a result, what is to be done?

With the responses to these questions in hand, the decision whether to collect the sample or not can be taken more reasonably. 